\title{
"Law and Gospel" in the Pentateuch organisation
}

\author{
James Alfred Loader \\ Universität Wien \\ Professor Extraordinarius, UNISA
}

\begin{abstract}
Both the structure of the overarching literary blocks in the Pentateuch (primarily containing either narrative or legal material) and the unfolding of its story line attest to the fact that the legal sections in the Pentateuch are subsumed under the narrative material. In light of the flexibility of the concept of "theme", the article argues that the theme of the Pentateuch can be expressed by the idea of תורה. The narrative sequence of the Pentateuch is reviewed from this angle to show that the general theme is manifested in specific parts of the text. The interrelationship between the motifs of divine providence ("Gospel") and obedience demanded from humans ("Law") demonstrate both the meaning of חור and the presence of this theme throughout the Pentateuch.
\end{abstract}

\section{TORAH}

Pointing out the encompassing - not to say dominating - role played by the concept of Torah on all levels of Jewish tradition would be stating the obvious. Even more so would be the claim that in Hebrew the Pentateuch is called the Torah. Somewhat less obvious but nevertheless well-known to all who have studied Biblical Hebrew, is the commonplace that hrwt means "law" as well as "instruction". Whereas dictionaries,' including

1 Cf Gesenius \& ([1915] 1962:875) (where the "law" does feature, but "instruction" is emphasised); Koehler \& Baumgartner (1958:1023); Brown, Driver \& Briggs ([1907] 1966:435-436) - to mention some well-loved sources in the tradition of theological faculties. 
theological dictionaries, ${ }^{2}$ often have no choice but to state the obvious, there remains the question as to the significance of this generally accepted information. Especially in Protestant theology, I suggest, this question is rather consequential in the light of the traditional reception of the Pauline motto of salvation by faith alone instead of by the works of the Law, as well as in the light of the importance in Lutheran theology of the bifurcation of "Law and Gospel". 3

Since the interpretation of the Torah concept goes hand in glove with the theme of the Pentateuch, both the concept itself and the idea of a literary theme need a short introduction.

The Greek translation vouós and Latin lex, obviate the tendency to counterpoise "Law" and "Gospel" in the sense that the former requires humans to achieve their own salvation by obeying the Law whereas the latter announces what God has done for humans by intervening in their world and lives. This is however such an oversimplification as to distort the picture as far as both the Old Testament and Pauline theology are concerned. $^{4}$ We shall not dwell further on such general considerations here, but proceed rather to develop an argument on the basis that the Torah, that is the Pentateuch of the Hebrew Bible, consists as much of narrative as of legal material.

\section{2. "THEME"}

In an essay of thirty years ago (Loader 1971:9-16), I worked with an understanding of "theme" comparable to that of Clines in that it is broader than "motif" without, however,

${ }^{2}$ Cf Liedke \& Petersen (1984:1032); this remains the case also when the complexity of the semantics of תורה is stressed (Kleinknecht \& Gutbrod 1942:1037-1039; Garcia Lopez 1995:631).

3 However, sharply formulated by Luther and, however, central to his theological thought, this polarity could not be fully upheld with reference to the Old Testament even by him, as appears from his Vorrede zum Alten Testament from 1523 (WA.DB 8,12f). Here he states clearly that the Old Testament also contains statements of grace so that the people of those times could also be saved "as we are" (wie wir) by "faith in Christ" (im Glauben Christi). Cf. Kaiser (1993:85). Beginning here, a committed deconstructionist could take the whole theology of Luther apart, but it is also possible to do the opposite - to reinforce it by reinterpreting it in the terms offered by redactional criticism.

4 Cf Rom 7:12: "The Law, then, is holy and the commandment is holy and just and good." See Limbeck 1997:115-124 (especially 119) on the two sides of the Pauline understanding of the Law; also Von der Osten-Sacken 1987:183, who highlights the ambiguity in the Pauline discourse as well. 
emphasising the aspect of causality in its relationship to significance or meaning (Clines 1976:484-485). These aspects (the first of which derives from Forster ([1927]1962:9394) seem important in order to work with the theme of a continuous narrative as I intend doing here. I would summarise my understanding of a literary theme as the shortest workable statement of the intention of a literary work in terms of its significance. Causal relationships play an important role when the literary work is a narrative.

"Workable" implies that the formulation of a theme is functional. It is meant to aid understanding, not only of the text itself, but also of the participants in the interpretative discourse mutually. In this sense the theme of a work is not in the work, but a construct based on interpretation of the text. It is of the same order as the genre or Gattung of the text in that genres are nowhere to be "found", but are construed abstracts of ways in which interpreters understand texts. So the genre of a text can be seen either in broader or in narrower terms depending on which function it is to fulfil. For instance, a psalm may be typified as a "lament" (Klagelied), or it may be required to contain more characteristics in order to be classified as an "individual lament" (Klagelied des Einzelnen). Again, the same psalm may also be called a "prayer of an accused" (Gebet des Angeklagten) because the classification criteria may be fine-tuned still further. The more criteria applied to it, the smaller the genre becomes; the less criteria, the more inclusive it becomes. The logic of "theme" works similarly. The formulation of a theme is relative to the inclusiveness wished by the interpreter. I would like to apply this to the Pentateuch, not however, to reproduce as many thinkable formulations of its theme as possible, but to contribute to the discussion of the significance of its meaning.

Whybray is quite confident about the theme: "The theme of the Pentateuch is not difficult to discern. It is the story of the birth and adolescence of a nation. Such a work is not in itself unique in the literatures of the ancient world, particularly in the world of late antiquity, nor is the fact that it begins with an account of the origin of the world unique" (Whybray 1995:9). But then he goes on to show in what ways the Pentateuch is unique, which qualifies his short definition appreciably. This enables us to formulate a theme on his own terms as follows (a kind of biblical Fortschreibung): "The theme of the Pentateuch is the birth and adolescence of a nation as the chosen people of the one, 
supreme God who is severe yet merciful, as his justice and promises show" (cf Whybray 1995:9-10).

This statement of the theme is narrower than that of Whybray's because several more criteria for its formulation have been brought into play. It is not at odds with Whybray's description and does full justice to his own understanding of the theme. This is borne out by the argument in the rest of his book, which is an unfolding of these contents as well as the conditions for and implications of understanding their meaning.

In his book, The theme of the Pentateuch, Clines puts forward a thorough argument that the theme of the Pentateuch is the partial fulfilment - which implies also the partial non-fulfilment - of the promises to the patriarchs. Although not directly derived from Clines, but dependent on his definition of "theme", Deist presents a similar statement (although he speaks of the Hexateuch instead of the Pentateuch, which is not really at issue in this context): "By means of such a definition of theme, we may say that the Hexateuch deals with God's power to remain faithful to promises which He had made to people who could not help themselves" (Deist 1988:4).

He also works with the promise-fulfilment schema, but his focus differs from both Clines and Whybray (or, more precisely, my restatement of Whybray; let us, in deference to Old Testament redaction criticism, say Whybray $^{\mathrm{R}}$ ). This seems to be quite significant. Whereas Clines offers an encompassing, general statement of the promise-fulfilment schema, Whybray ${ }^{\mathrm{R}}$ works with the justice (severity) and love (mercy) of God. Deist, however, only focuses on God's power, notably his power to remain faithful to his people. Although it may be queried whether the concepts of "power" and "remaining faithful" can be comfortably fitted into a definition where they stand in a causal relationship, the point is that the theme for Deist has much more to do with God's involvement with people than with what he demands of them. They are only humans "who cannot help themselves". Implication: Sola gratia. Just "Gospel", no talk of the Law, not even as far as that part of the Old Testament is concerned which is Law par excellence and where massive blocks of legal material in the form of several codices and collections occur. 
Who is right? Predictably, in the light of my introductory considerations, I should answer, "All three". Equally predictably, in the light of scholarly convention, I would answer that it is not so simple. Clines is safe with his formulation of the theme, because it is broad enough to allow for a lot. Whybray ${ }^{R}$ in his fortgeschriebene version allows for God's justice, which implies a law, as well as God's love. This version of the theme works with "Law" and "Gospel". So, Whybray ${ }^{R}$ can be accommodated by Clines. And can Deist be accommodated by Whybray ${ }^{R}$ ? I think so - if the rest of my argument holds good.

If we stay with the promise-fulfilment schema as formulated by Clines (incorporating Whybray ${ }^{5}$ ) and Deist, we may broaden the concepts used in the way scholars do with genres. We may subsume promise and fulfilment under one highly theological signifier, "providence". One of the advantages of this is that it can be used to express various kinds and expressions of divine grace. For instance, it can express the motif of the protection of the matriarch (Gn 12:10-20;20:1-18;26:1-116) as adequately as the "liberation" of the Exodus, which to Deist (1988:4-5) becomes a leading expression of promise: “ ... a promise of help in the midst of powerlessness or, rather, ... a motif of liberation from powerlessness". T Then the counterpart of God's help is to be formulated as "discipline" in order to account for the aspect of justice as done by Whybray. The law is there to order the community of God's people and in this sense fulfils a disciplinary function. So: providence and discipline instead of promise and fulfilment

One step further in this direction would yield the following: God's providence and discipline can be subsumed under one concept: Torah. Not: Torah and Gospel, but only Torah. The considerations that follow, will argue that the concept of "Torah" contains both elements. I propose to proceed by analysing the story line of the Pentateuch with

\footnotetext{
5 At the end of his book Whybray (1995:136) thinks it is justified to say that he has "amply demonstrated" that the "primary theme" of the Pentateuch "is undoubtedly that of the promises made to the patriarchs from Abraham on." This underscores the fact that his views can be accommodated by those of Clines and it also illustrates what I am arguing, viz the flexibility of the concept of "theme".

${ }^{6}$ Cf Loader (1994:28), where I have studied this motif in another context.

7 I think the political background of the South African eighties, when this was written, shimmers through these ideas and I wonder whether they will again become topical in another way as the new millennium progresses.
} 
due regard to the redactional perspective. The argument is that, if we do this, we shall find that the narrative parts subsume the legal material so that we end up with the "Law" incorporated into the narration of God's ever provident intervention in Israel so as to achieve the fulfilment of his promise, that is "Gospel". A law-incorporating gospel is a torah.

\section{PENTATEUCHAL BUILDING BLOCKS}

The description "Torah" or "Instruction", given to itself by Deuteronomy (Dt 4:44; 30:10; $31: 9,12)$ was later extended to include the whole Pentateuch. ${ }^{8}$ The major section on the giving of the Law at Sinai (Ex 20-Nu 10) ${ }^{9}$ can be read as a narrative on instruction of the cultic community. Also the stories of Genesis can be read in a similar vein, since they contain such references ${ }^{10}$ and therefore provide the ritual stipulations of the following legal sections with a basis. On the one hand, the story of the sojourn in the wilderness (Nu 10-36) is narrative, and on the other it contains much cultic material. The legal material in the Book of Deuteronomy is prefaced by the Decalogue (contained in Dt 4:445:6-22). Exactly the same thing happens with the legal material in the "Sinai Pericope", where the collection of major law codices is likewise prefaced by the Decalogue (Ex 20:1-17). This link between the legal blocks and their respective versions of the Decalogue becomes even more striking in the light of Braulik's observation that the order in which the laws of Deuteronomy appear in this book, corresponds to the order of the commandments in the Decalogue (Braulik 1988:231-256). One cannot fail to notice the organisation of the material into a first and a second compositional body. This gives the labelling of Deuteronomy as the "Second Law" (deuteronomy) immediate redactional relief and characterises its contents as a collection of laws in their amended version.

\footnotetext{
* Kaiser (1998:18); cf, for a more general discussion, Kaiser (1993:300, 329ff).

9 This block contains the Decalogue (Ex 20:1-17) as well as the main legal collections of the Book of the Covenant (Ex 20:22-23:33), the cultic laws brought together in Ex 25 - Lv 15 as well as the Holiness Code (Lv 17-26).

18) $\mathrm{Eg}$ in $4: 3-4 ; 9: 4-6 ; 12: 7-8 ; 14: 18-20 ; 15: 9-10,17-18 ; 17: 23-27 ; 28: 16-18 ; 31: 54 ; 35: 1 ; 46: 1$.
} 
These two central blocks are the mainstay of the legal collections. They may be presented as follows:

\section{Figure 1}

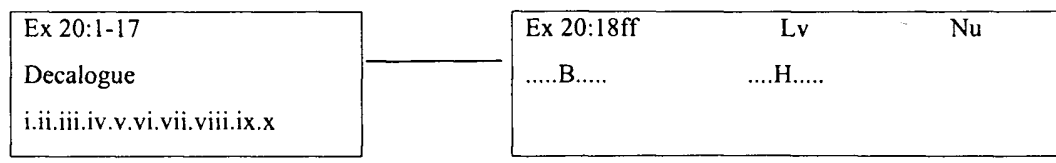

\begin{tabular}{|l|c|}
\hline $\begin{array}{c}\text { Dt 4:44-5:22 } \\
\text { Decalogue } \\
\text { i.ii.iii.iv.v.vi.vii.viii.ix.x }\end{array}$ & Deuteronomy 5 ff $\rightarrow$ \\
\hline
\end{tabular}

However, both are framed at their beginnings and at their endings with blocks of narrative material: Prior to the Exodus-Numbers block is Genesis 1-Exodus 19. At its ending there is the Wilderness Story of Numbers 10-36. The latter includes legal, cultic matter and the former contains instructions and a formal Law (the so-called commandments to Noah of Gn 9:4-6) as well as many references to cultic practices and accompanying commandments (see footnote 10 above).

In similar fashion, the Deuteronomy block is quite literally prefaced by the socalled introductory narrative (Dt 1-4) and rounded off by a block of narratives picking up the form of Moses' speech with which the whole book begins (Rahmenerzählung), about his songs, successor and death.

The whole composition of building blocks may be presented as follows: 


\section{Figure 2}
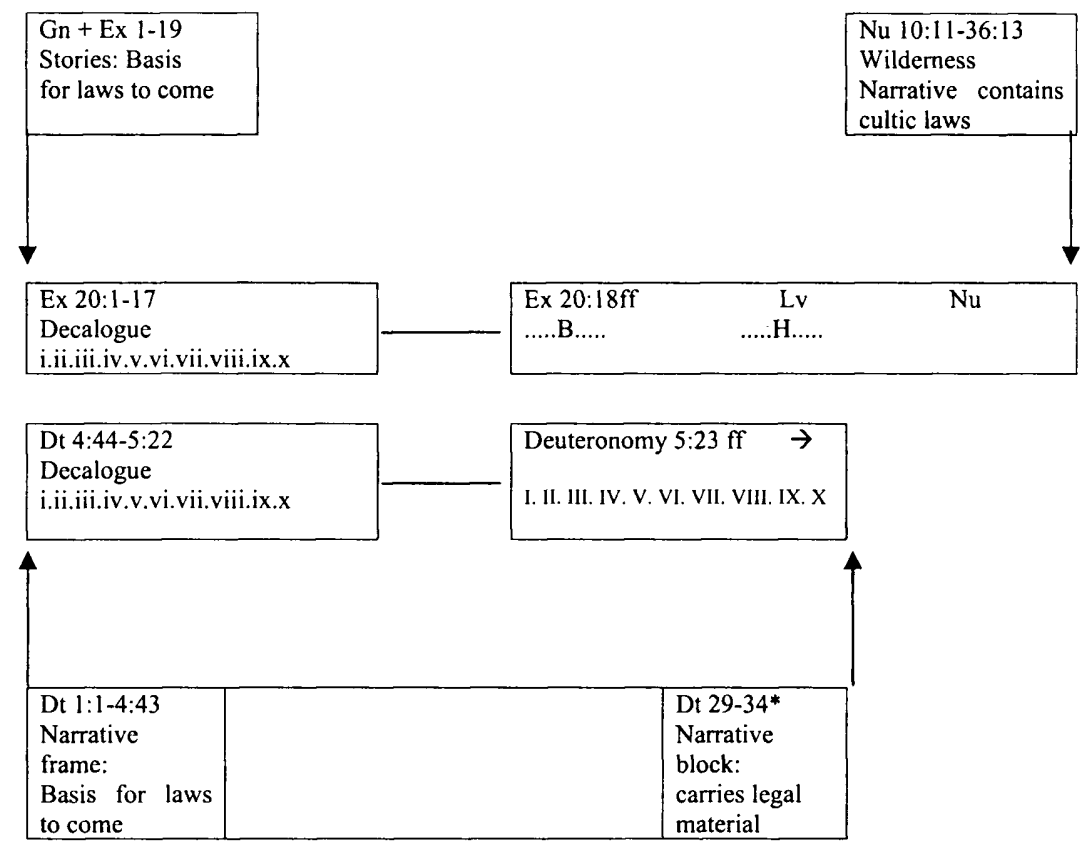

\section{THE STORY LINE}

Let us now briefly review the story line of the whole Pentateuch and pay particular attention to those aspects that are relevant for my thesis.

\subsection{The Primeval Narrative (Gn 1-11)}

The story begins with creation and continues with a series of human efforts to frustrate God's intentions for them. The stories of the Fall, Cain and Abel, the Flood and the Tower of Babel all attest that God continues to show kindness to humans despite their ever returning sin. Even where the motif of promise is not found, the narrative thrust is promising, creating an expectation of reaching God's goal. In this context we find 
references to the cult betraying a priestly legal interest (cf Gn 4:3-4) while the commands given to Noah complete with Kosher laws and other instructions comprise the first real Torah in the technical sense of the word. This in itself is an instance of the Law being built into the narrative of God's mercy. Ending as it does on the negative note of disarray at Babel, the rhythm of ups and downs creates an ominous effect and as such calls for another new beginning (cf Loader 2000). This is brought about with the help of a number of genealogies which do not only paste the sections together, but integrate them with each other and with the following Patriarchal History (cf Van Seters 1992:213). The story of humanity becomes the story of Israel.

\subsection{The Patriarchal History (Gn 12-50)}

First comes a drastic reduction from humankind to one person: Abraham. God promises him a great offspring, an own land and blessing for his descendants and for humanity as a whole. His grandson, Jacob, becomes the father of twelve sons from whom spring the people of Israel (Gn 49:28). The reduction starts to move in the opposite direction: humanity $>$ Abraham $>$ Israel. Between these poles the motif of Israel as the chosen people is developed, showing that the narrative is to become the story of Israel under God's protection and his special blessing, that is his providence. The repeating of these promises, also to the other patriarchs, serves to reinforce the idea (Gn 17:4-8; 22:17-18; $26: 3-5,24 ; 28: 13-15 ; 35: 10-12)$. Another reinforcement of God's providence which cannot be accounted for by the promise idea alone, is the repeated use of the motif of his protection of the matriarch. Since two of them are barren, the offspring is endangered, which dramatises God's care and therefore the expectations for the future. Once more the providence of God is linked to the survival of the people in the Story of Joseph. Time and again the same idea is expressed in a variety of settings: the providentia Dei.

Where the Primeval narrative ends on a threatening note, the Patriarchal History proceeds in a promising strain. It does contain elements of grave human sin among the patriarchs themselves (Abraham and Isaac are cowards, Jacob is a fraud, the tribal fathers are conceited, murderers and liars), but the function of these is precisely to enable the main narrative thrust to develop: all of this is continuously overcome by God's providence. as he keeps looking after his chosen in their daily needs and dangers. The 
ups and downs of the Book of Genesis cannot, therefore, be called "threatening". Since the journey of the tribal fathers to Egypt saved their lives, the book does not end on a negative note, but on a positive one." Only then the line sinks again as a new crisis threatens the Israel family at the beginning of the Book of Exodus.

\subsection{The Exodus Narrative (Ex 1:1 - 15:21)}

While בני ישראל at the end of Genesis means "the sons of Israel (= Jacob)", at the beginning of the Book of Exodus the meaning is "the children of Israel (= the people)". It is clear that the clan has become a nation in Egypt. The land that saved the lives of the patriarchs has become the land of their slavery and a threat to their further existence. Again the intentions of God are in jeopardy and again God intervenes. This time he calls Moses to mediate between him and humans (Ex 3-4). Moses then leads the people out of their crisis under many signs of God's care and protection (Ex 7-12).

In this narrative section the motif of God's care is combined with that of human $\sin$ on a grand scale. The liberation from Egypt has ever since remained the orientation point of Israelite faith, the outstanding symbol of his love for his people. But even so, the narrative does not shrink from portraying Israel as a very unthankful people who continuously lacks faith. Where these two motifs are associated so as to develop a diminuendo in the Primeval Narrative (ending on a negative note) and a crescendo in the Patriarchal History (ending on a positive note), here they are used sostenuto (in a sustained parallel). Precisely this interplay of God's grace and human failure to respond appropriately is taken up and extended by the next unit.

\subsection{The journey to Sinai (Ex 15:22 - 18:27)}

Although the story of the road to Sinai is short, it is important, for here we have one of the clearest cases of Israel's rebelliousness against God and his providential measures. A notable feature of the Israelite narrative tradition is given its classical expression here. The national history is not self-glorifying, but time and again focuses on the sin and undeserving behaviour of the people. This motif forms a counterpart to the con1 Deist (1981:82) in a study guide for the University of South Africa (BSA 100-E), is of the opposite
opinion. 
sciousness of being God's chosen people among all other nations. Not only is the counterbalance to the so-called particularism in the Old Testament given in universalistic statements (e g Deutero-Isaiah), but especially in this remarkable trait of self-criticism. The theologoumenon is obvious: Sin should be honestly confessed and made explicit. ${ }^{12}$

\subsection{The sojourn at Sinai (Ex 19:1-Nu 10:10)}

As one of its two principle "building blocks" (cf Figures 1 and 2 above), this section is the longest in the whole Pentateuch. Its contents have become central to Judaism as well as to recent Old Testament scholarship (cf Van Seters 1994:247-248). It contains eight subsections, including the Decalogue (Ex 20:1-17), the Book of the Covenant (Ex 20:2222:33) and the Holiness Code ( $\operatorname{lv}$ 17-26), in addition to several legal collections on cultic matters. Although these collections are of different origin, they have been built into the same narrative context. Within this unitary framework they are integrated into the single literary composition. Not only can this be seen in the overall frame (Ex 19:1-25; Nu $10: 11 \mathrm{ff}$, but also in narrative references relating the legal material to earlier episodes in the story line. For example, substantiating reference is made to what God had done to the Egyptians (Ex 19:4; cf Van Seters 1994:273), specific laws are substantiated by reference to Israel's previous experiences ( $i$ a Ex 22:21; 23:9; Lv 19:34; cf Gemser 1953:50-66). Moreover, the laws are presented as the stipulations of the covenant between God and Israel, which is told in narrative form. The fundamental concept of the covenant carries the collections of laws both theologically and as narrative. Instead of being made "the" centre of the Old Testament in Eichrodtian fashion, the "centrality" of the covenant should be seen in its literary function as this is shown by redaction criticism. The effect of this use of the covenant is that it forges the laws into a unity, not only among themselves, but it also and particularly integrates them with the narrative of God's dealings with humans. That is what the covenant is all about. It tells about the love of God for humans and at the same time it requires these humans to respond in faith. The

\footnotetext{
12 This is not only fundamental for Christianity in general (including Pauline theology), but also a comerstone of the Reformation. Not for nothing is the concept of consciousness of guilt and the confession of $\sin$ the first of three main sections of the Heidelberg Catechism, since repentance is presented as the doorway to grace and forgiveness. The narrative sequence of the Pentateuch could serve as a much more solid biblical foundation for this theology than any given collection of dicta probantia.
} 
laws are there to enable them to respond in faith. ${ }^{13}$ There is no stronger way of expressing the ambivalence of "Gospel" as well as "Law", than by the concept of the covenant. "Telling" of God's providence intimately involves "requiring" a response in terms provided by the law.

\subsection{The forty years in the wilderness (Nu 10:11-36:13)}

The rest of the Book of Numbers forms the framing block of narratives illustrated in Figure 2 above. The stories of Israel's further travels, conflicts and endeavours to reach the Promised Land are told with constant recurrence of the motif of their sin of disobedience and insubordination. This time the consequences are grave, since their punishment is that they have to wander around the wilderness for another forty years $\mathrm{Nu}$ 14:26-35). Even Moses is punished for withstanding God (Nu 27:13-14). The distinctive mark of the Pentateuch is again expressed in the combination of the motifs of divine guidance and human disregard for his will.

\subsection{The Book of Deuteronomy}

The last section of the Pentateuch is a compositional unit presented almost in its totality as a sermon of Moses shortly before the crossing into the Promised Land. Here too the history of events narrated in the earlier parts of the Pentateuch are referred to, which, as in the case with the Exodus-Numbers Block, incorporates Deuteronomy into the whole work.

The style of Deuteronomy is theologically important. The first introduction (Dt 1:1-4:40) is strongly homiletic. In telling about the past, it preaches. The motifs of the narrative sermon are once more what God has done for Israel and how his wrath was excited by the people's disobedience. Building on the dialectic of the two sides of "Gospel" and "Law", the sermon becomes a parenesis calling Israel to faith. In the light of the history related, this is in fact a call to repentance so that the future may be prosperous. The second introduction (Dt 4:44-11:32), which is also of a parenetic character, the Second Decalogue (Dt 5:6-21) and the famous שמע (Dt 6:4-5) are found in

\footnotetext{
13 This too should be quite familiar to all Protestants of Calvinist provenance who continually hear about the "two sides" of the covenant. Cf the injunction in the Baptism Formulary to accept commitment, "since all covenants have to sides."
} 
this section. The latter has become the summary of Jewish faith and is (in the context of the chapter) remarkable for its combination of, on the one hand, Israel's sin and inability to provide for itself and, on the other, the love of God and his care (Dt 6:10-11; 9:6, 24), which includes the gift of the Torah. ${ }^{14}$

The Law proper follows in Deuteronomy 12-26. This Torah is "the words of the covenant" (Dt 29:1), which is to be understood as the second covenant after the Sinai covenant, written in a book by Moses himself (Dt 31:24). The laws are partly repetitions of laws in the Book of the Covenant (Ex 20:22-22:[19]33), partly formulated somewhat differently and partly without parallel in the Book of the Covenant. In these laws the so-called centralisation of the cult is prescribed as a measure to safeguard the monotheistic singularity of Israel's religion.

The book, and with it the Pentateuch, ends with a number of important shorter narrative sections: Blessing and curse (Dt 27-28), the second covenant (Dt 29), the farewell speech (Dt 31), song (Dt 32) and blessing (Dt 33) of Moses, as well as the story of his death (Dt 34:1-8). The book and, again, with it the Pentateuch, looks at the future since is tells of Joshua as the successor to Moses. On the one side, the death of Moses marks the end of (a) the definitive period in Israel's history with God, and on the other side this clear period is linked with the first of the socalled "Former Prophets". The Pentateuch is truly the foundation of the realisation of God's will for Israel. Indeed a foundation of such magnitude has its importance marked much more effectively when it is brought to a close and then linked to what it is a foundation for. In this sense it is no wonder that the redactors both discarded the "natural" ending of the theme of promise and fulfilment and reorganised it as the occupation stories in the Book of Joshua to begin a whole history of which the Pentateuch remained the foundation. For it is the ultimate statement of Law and Gospel in Israel.

\section{A COMMON DENOMINATOR OF READING STRATEGIES}

Whether one reads the Pentateuch as a travel story (of Israel), or biography (of Moses) as Van Seters (1994) does on a grand scale, or whether one opts for a structural design as

\footnotetext{
14 The gift character of the Law is already apparent in the first introduction (Dt 4:8). Particularly close is the combination of "Law" and "Gospel" in Dt 6:18: You should do good (a: Law), so that it will be well with you in the land that God will give (b: Gospel of what is to come), as he has promised the fathers (c: Gospel of what God has done in the past). The benevolent nature of the Law is seen in the whole introduction, right through to $\mathrm{Dt} 11$.
} 
that presented by Zenger (1996:37), ${ }^{15}$ the story line or the narrative sequence remains the same. All of these propositions for reading strategies work with legal blocks incorporated into the narrative material, not the other way round. This can be illustrated in the following way:

\section{Figure 3}

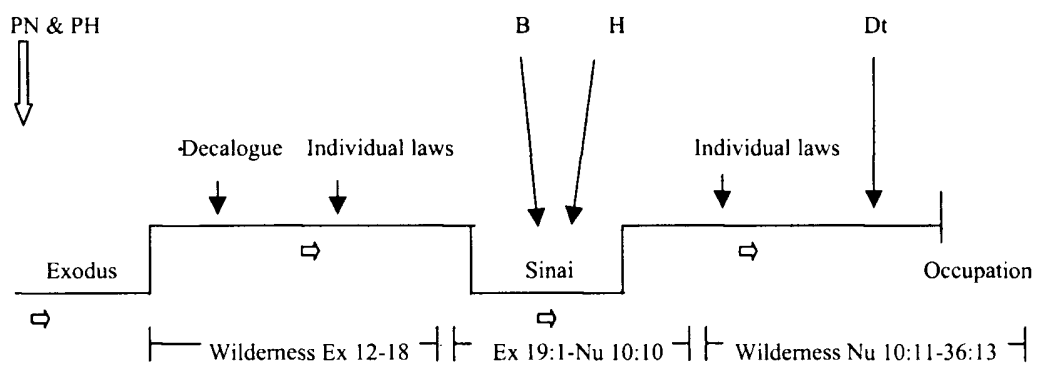

We may conclude, then, that Deist was right. Although he does not use this terminology, his presentation of the theological import of the books that we have been considering is that they proclaim what God does for helpless humans. What we have achieved, I think, is the realisation that this claim cannot be made too rashly if the biblical substructure is to be appreciated. Simply claiming that the "Law" has been overcome by the "Gospel" loses sight of the nature of the biblical Torah and of the inner character of the Gospel. Together they constitute an appeal which calls for a response. If this response is faith, then it needs a form to express itself in. In this regard there is a primary as well as a secondary factor in the Pentateuch. These correspond to the story's literary function as a statement of grace and the requirements of responding love grafted upon it in the second place. I think this corresponds in turn to the classical distinction in Christian dogmatics between God's opus proprium and his opus alienum. His primary act is the grace of his love. The secondary counterpart, the other side of the same coin, the reverse without

\footnotetext{
is He finds a concentric pattern in the composition of the whole Pentateuch built around the Book of Leviticus, which itself is a concentric structure around the motif of "atonement" in Lv 16-17.
} 
which there is no obverse, is his appeal for counter-love. If the first opens heaven, then the second makes our way there endurable.

\section{Works consulted}

Bosman, H L \& Loader, J A (eds) 1988. Old Testament storytellers. Cape Town: Tafelberg.

Botterweck, G J, Ringgren, H \& Fabry, H-J (Hrsg) 1970-1995. Theologisches Wörterbuch zum Alten Testament, Bd 8. Stuttgart: Kohlhammer.

Braulik, G 1988. Die Abfolge der Gesetze in Dt 12-26 und der Dekalog, in Studien zur Theologie des Deuteronomiums. Stuttgart: Kohlhammer. (SBAB 2.)

Brown, F, Driver, S R, \& Briggs, C A [1907] 1966. Hebrew and English lexicon of the Old Testament. Oxford: Clarendon.

Clines, D J A i976. Theme in Genesis 1-11. CBQ 38, 483-507.

- 1978. The theme of the Pentateuch. Sheffield: Department of Biblical Studies, University of Sheffield. (JSOT Suppl 10.)

Deist, F E 1988. The Hexateuch, in Bosman \& Loader 1988:1-42.

Forster, E M [1927] 1962. Aspects of the novel. Harmondsworth: Penguin.

Garcia-López, F 1995. s v hrwt, in Botterweck, Ringgren \& Fabry 1970-1995:597-637.

Gemser, B 1953. The importance of the motive clause in Old Testament law. SVT 1, 5066.

Gesenius, W \& Buhl, F [1915] 1962. Hebräisches und aramäisches Handwörterbuch über das Alte Testament. 17. Aufl. Berlin: Springer.

Jenni, E \& Westermann, C 1984. Theologisches Handwörterbuch zum Alten Testament, Bd 2. Zürich: Theologischer Verlag.

Kaiser, O 1993. Der Gott des Alten Testaments: Theologie des Alten Testaments, Teil I. Grundlegung. Göttingen: Vandenhoeck \& Ruprecht.

- 1998. Der Gott des Alten Testaments: Wesen und Wirken. Theologie des Alten Testaments, Teil 2. Jahwe, der Gott Israels, Schöpfer der Welt und des Menschen. Göttingen: Vandenhoeck \& Ruprecht.

Kittel, G \& Friedrich, G (Hrsg) 1933-1979. Theologisches Wörterbuch zum Neuen Testament, Bd 4. Stuttgart: Kohlhammer. 


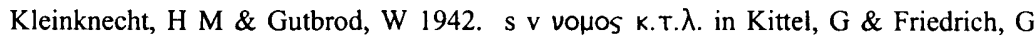
1933-1979:1016-1084.

Koehler, L \& Baumgartner, W 1958. Lexicon in Veteris Testamenti libros. Leiden: Brill.

Liedke, G \& Petersen, C 1984. s v תורה Weisung, in Jenni \& Westermann 1984:10321043.

Limbeck, M 1997. Das Gesetz im Alten und im Neuen Testament. Darmstadt: WBG.

Loader, J A 1971. Die hantering van motiewe in die Ou Testament. HTS 28, 9-16.

- 1994. David and the matriarch in the Book of Ruth. IdS 28(1), 25-35.

- 2000. Rhythm in the Primeval Narrative. OTE 13. (Forthcoming.)

Van Seters, J 1992. Prologue to history: The Yahwist as historian in Genesis. Zürich: Theologischer Verlag.

- 1994. The life of Moses: The Yahwist as historian in Exodus-Numbers. Kampen: Kok. (CBET 10.)

Von der Osten-Sacken, P 1987. Das paulinische Verständnis des Gesetzes im Spannungsfeld von Eschatologie und Geschichte, in Evangelium und Tora. München: Kaiser. (ThB 77.)

Whybray, R N 1995. Introduction to the Pentateuch. Grand Rapids: Eerdmans.

Zenger, E (Hrsg) 1996. Einleitung in das Alte Testament. Stuttgart: Kohlhammer. 